\title{
The Application of New "Theory and Practice Pouring Model" in Training of Preschool Education Major in Local Colleges and Universities
}

\author{
Xiaoyi Wang ${ }^{1}$ \\ (Xi'an University, Xi'an, Shaanxi, 710065)
}

\begin{abstract}
Keywords: Theory and practice pouring model; Local colleges and universities; Preschool education
\end{abstract}

\begin{abstract}
Under the background of education reforms and developments that colleges and universities are transforming into applied technology, aiming at the long-standing practice that the education sector has not solved, the preschool education major of local colleges and universities innovate "theory and practice pouring model" of talent training model, make practice and reform focus on the knowledge formation and generation of reflective preschool teachers, so that the relationship between theory and practice becomes a state of "pouring" molding, implement a real situation training mode, promote the teaching process and meet professional requirements, improve the preschool education students' teaching ability and promote their professional experience in preschool teachers.
\end{abstract}

\section{Introduction}

In February of 2012, the Ministry of Education officially issued Professional Standard for Kindergarten Teachers (Trial) (hereinafter referred to as Professional Standard). It is the basic requirement of the country for the professional quality of qualified kindergarten teachers. It also reflects the new requirements put forward by the social development and education reform on the professional quality of kindergarten teachers, and especially attaches great importance to the ability of preschool teachers to practice teaching.

According to the requirements of the Ministry of Education that "guide a branch of colleges and universities to transform to applied technology type ones", many local colleges and universities have become pilot institutions for transformation and development, and preschool education majors have also become pilot projects for transformation and development. Combining the characteristic of local colleges serving localities, some pilot colleges and pilot programs actively adjust their ideas, fully implement the transformation and development, compile Mid-term Plan for Professional Construction and Development, introduced Promotion Plan for the Transformation of Colleges and Universities to Applied Technology Ones, formed The Measures to Speed up the Transformation and Development of Colleges and Universities and other supporting measures. The application personnel training system experiences continuous improvement. According to the requirements of "two transformation and two combination" (transformation position and transformation development, school-enterprise integration, and integration of production and education) and "three connections", focus on school-enterprise cooperation, school-locality collaboration and form a "multi-level and multi-path" application talent training system.

Under the background of the reform and development of school education, the preschool education major of local colleges and universities are precisely aiming at the long-term practice problems that the education sector has not solved well, and the ones which are existing in practice and theory links of solving problems in reality, and focusing on the questions: What does practice mean for talent cultivation? Why is our contemporary education far from practice? What is the best combination of students' theoretical study and educational practice? What are the characteristics of the practical problems in preschool education personnel training? How does practice avoid low-level repetition? and so on. Then it studies the regional characteristics of local colleges and universities as well as the practical problems and pressing issues of preschool education.

Taking preschool education major of Xi' an University as an example, starting from the reform of talent cultivation model, the model of "theory and practice pouring" has been implemented in an 
all-round way, and the practice-oriented integration of curriculum teaching reform and practice link reform has been carried out. Finally, the practice reform is focused on the knowledge formation and generation of reflective preschool teachers, so that the relationship between theory and practice is no longer a separate state of "rebar" and "silt", but the state of "pouring" molding. Implement a training model based on the real situation that reflects "theory and practice pouring model" to promote the teaching process and the professional requirements can connect to each others, improve the professional practice experience of preschool education major students and the practicing ability of preschool teachers. From the training level, from the original secondary and college education to the current undergraduate and graduate education, the training level moves up. From the training mode, from the original skill-based and knowledge-based curriculum teaching system to the practical integration of reflective practice integrated curriculum teaching system, the training mode achieves some results.

\section{The Definition of New "Theory and Practice Pouring Model"}

The new "theoretical and practical pouring model" is a concise expression of the knowledge model established between the theoretical core and the operating path of preschool education major in local preschool education for many years.

This model refers to the transformation of the knowledge composition of preschool teachers into the dynamic construction of "pouring"under the support of the practice community. In the process of cultivating students' practical knowledge, the preschool education major regards the theory as reinforcement, students' original experience as sediment and practice as pouring moulding. In the practice community constructed by universities and kindergartens, through continuous reflection and refinement, personal experience and collective experience are exchanged, and various elements of practice are integrated to create a pouring effect.

The "new type" firstly refers to the change of the practice role, from the traditional "craftsman" knowledge holder or skilled person to the reflective practitioner. Secondly, it refers that the new path of practical teaching is the interaction between teachers and children, teachers and teachers in a specific context. It is a process of construction of two-way intersubjectivity and the realization of "pouring" "theoretical core" and "multiple factors of practice" in the real field, and an unification of dynamical generation of students' practical knowledge, the achievement of talents training goals, curriculum systems and practical processes.

\section{The Content and Characteristics of New "Theory and Practice Pouring Model"}

\section{Content}

Clarified the principle of new "theory and practice pouring model"

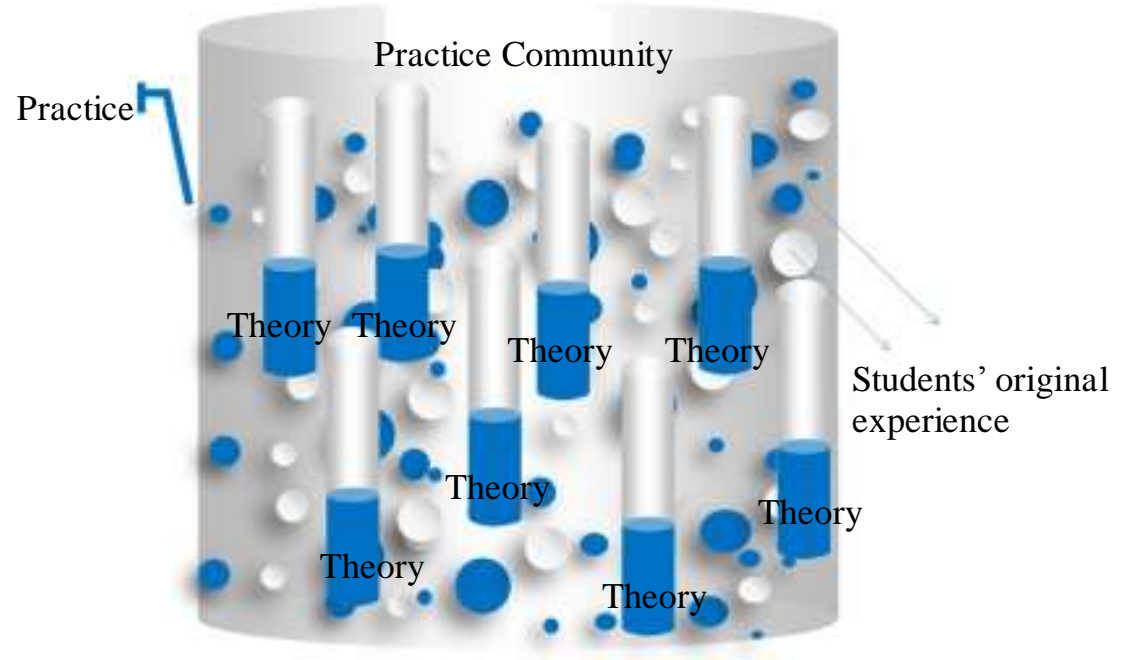

In the process of cultivating students' practical knowledge, preschool education major of local 
colleges and universities regard theory as reinforcement, students' original experience as silt and practice as pouring model. In practice communities constructed by universities and kindergartens, through continuous reflection and refine, personal experience is resonated with collective experience, all factors of practice are integrated, and pouring effects produce, students' practical knowledge is dynamically generated.

Established a dynamic knowledge-generating mechanism of "theory and practice pouring model"

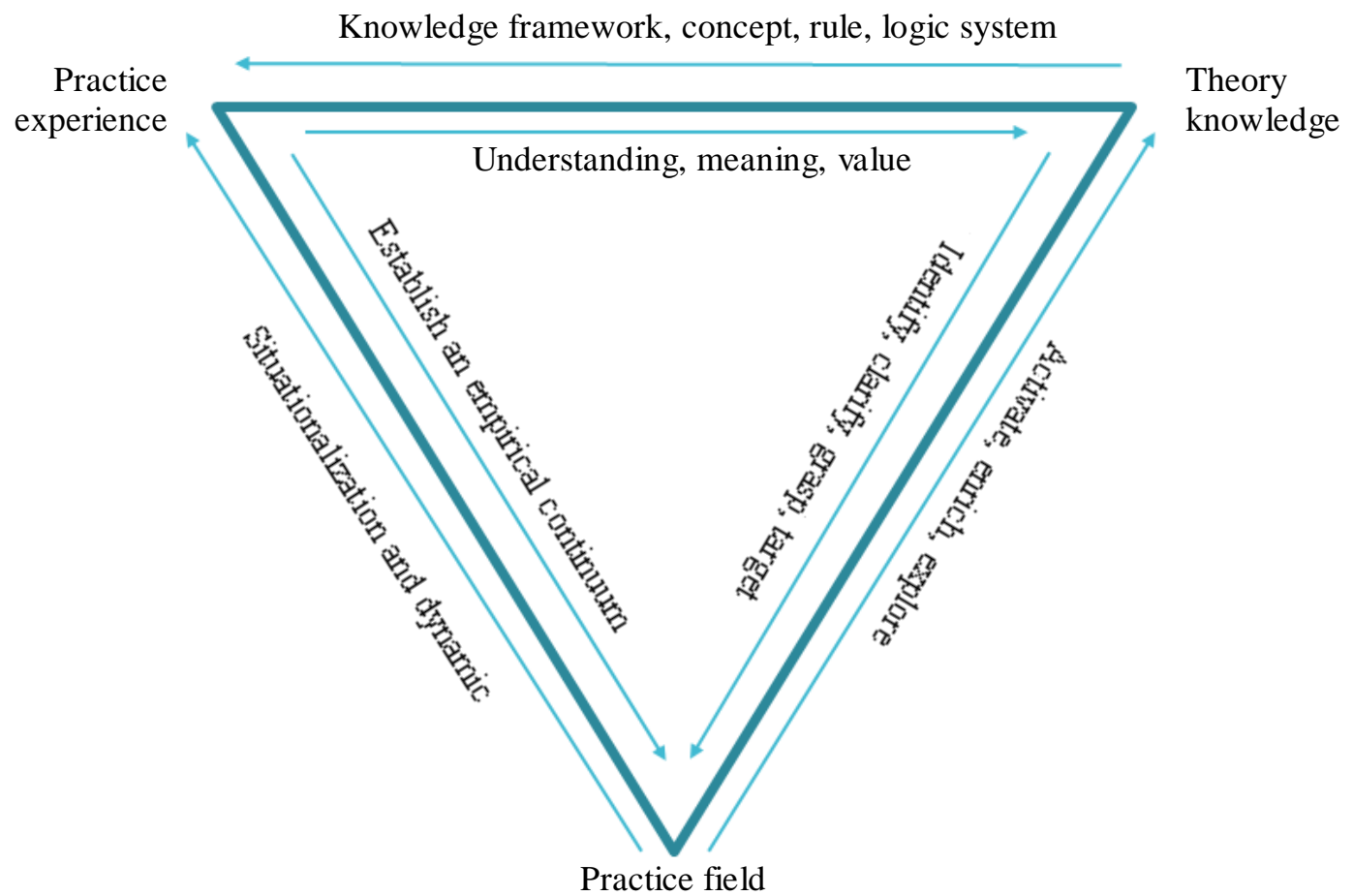

Practitioners describe the activities or processes in real field, capture the scene to feel, mirror the image or transpose to understand themselves, reflect with the practice community, reflect questions and solve problems, activate the theory knowledge, situationally understand theory and reconstruct theory and transform reflective thinking into practice. Eventually, the self-conscious state of the reflective practitioner is formed: Practitioner always considers himself as a learner and maintains an open attitude. He explores and researches to obtain tools that support his professional development, treats theory with a critical attitude, and can understand theory and practice. Correlate and master the corresponding transformation methods to form a dynamic mechanism for knowledge acquisition.

In practice, a new "theory and practice pouring model" has been formed 


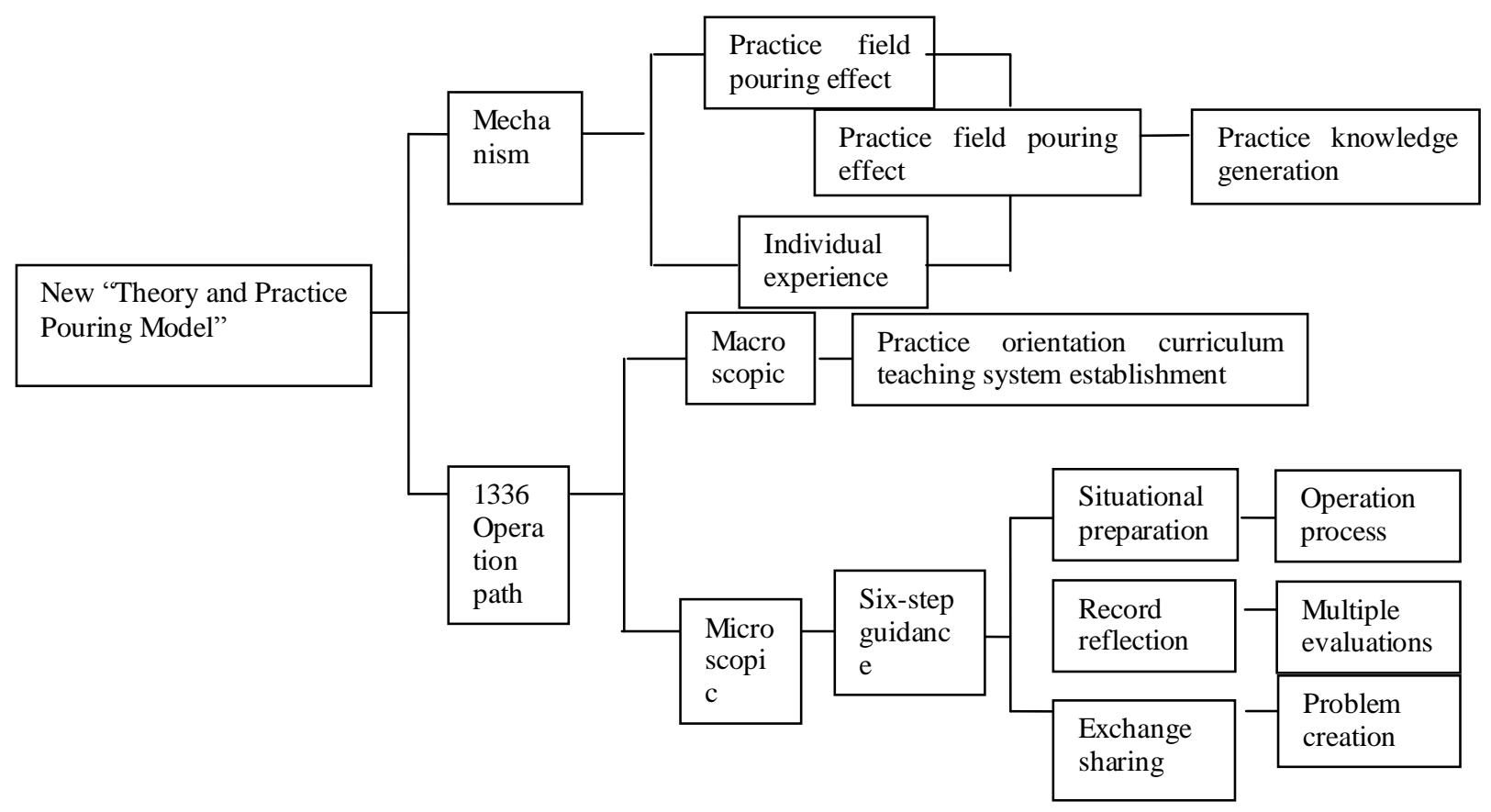

From the macroscopic path, this model creates school for the development of kindergarten teachers and establishes a community of practice through cooperation between colleges and kindergartens. As a result, this model focuses on talents training mode, training room system, practice, reform of internship system and curriculum system (satisfying courses on-campus training, practice courses off-site field practice of the backbone of kindergarten teachers and students) all through and establishes a practical support platform system, establishes a standard system of professional skills for preschool teachers, dual tutors to guide graduates' thesis and internship system.

The curriculum construction centers on the training objective of "reflective preschool teacher practitioners" and conducts a fundamental system integration of traditional "three learning, five fields, and professional skills" curriculum. The goal is to create reflective practitioners and transform teaching materials. The presentation of knowledge creates a good ecological teaching environment.

From the microscopic path, taking the whole practice community as the carrier and the full-practice mentor as the identity of the visual-information staff, a six-step operating method is formed that situation preparation-process-record reflection-exchange sharing (class, grade group, the largest community group)-problem creation, making students form basic reflection skills: describe activities or processes, capture the scene to feel, mirror or transpose to understand themselves, practice community reflective dialogue, question and solve, activate theory knowledge, situationally understand and reconstruct theory, turn reflective thinking into action.

\section{Characteristics}

\section{Immediate Interaction}

Interaction is a quick reaction and live insight of the current experience. The objective conditions in practical interaction include students' equipment, books, instruments, toys, and game materials, the actual practice conditions of kindergarten, and the social structure of the various situations in which students participate; the internal conditions in practice interaction refer to the abilities and needs of students. Practice instructors help students to achieve immediate interactions, and creatively interact external objective conditions with students' intrinsic capabilities and needs. This immediate interaction is the microscopic mechanism of action of "pouring model" expression.

Space-time Continuity of Experience

This model enables practice knowledge to be generated in students' growth, transformation and accumulation. Teachers guide students to clarify this direction, recognize and understand students' existing experience, and perceive their potential aptitude for judgment, which is in line with 
students' growth direction. In the real field of kindergartens, active work is taken to provide time and space for students to reflect the content of the assignment and themselves to gain the experience that the assignment is relatively complete and meaningful to the individual. And then they will move on to the next one by taking this experience as motivation and foreseeing future experiences. Learning becomes a process of developing practical knowledge in experience and for experience. Through the reflection of the continuity of time and space, we can obtain empirical meanings, and realize the transformation from original experience to reflection on refining experience and from experience to completeness. In the process of transformation, theory knowledge has infiltrated into complete experience to realize the pouring effect of theory and practice.

\section{Main Problems Solved in Teaching of New "Theory and Practice Pouring Model"}

\section{Solve the Problem of System Fragmentation}

The core of new "theory and practice pouring model" is the establishment of a practical community through cooperation between colleges and kindergartens. It is to establish a school for the development of kindergarten teachers and participate in and communicate with the practice community in terms of training mode, curriculum system, training system and system construction. The negotiation and final settlement will connect to talents training mode, training system, curriculum system, and system construction to form an integrated linkage between disciplines and majors, majors and professions, teachers, students and society, to change the state of kindergartens that simply accept intern students, and make students improve their practical ability before entering the job and become integrated with the sustainable development of the professional after entry. Its organizational model is an organizational model of cooperation between colleges and kindergartens. A team of experienced kindergarten teachers and college teachers are responsible for cultivating and instructing preschool education intern students. Preschool education teachers and intern students form a community of practice and sharing responsibility for teaching and management work of the class. As teaching assistants, internship students assist and observe instructors' teaching to gain experience. Kindergarten teachers can also serve as lecture teachers and training teachers in preschool education programs. The kindergarten teacher development school is a kind of functional creation. It is a collaborative community of universities and kindergartens that aims to promote the professional development of kindergarten teachers. On the one hand, it is built in the kindergarten as a kind of new functional creation of the kindergarten. The kindergarten does not only promote the physical and mental development of children, but also promotes the professional development of kindergarten teachers; on the other hand, it also functions as the extension of preschool education major of colleges and universities. It is students' "learning laboratory". The base for cultivating preschool teachers extends from colleges and universities to kindergartens, realizing the rapid professional orientation prior to entry into employment and the sustainable development after entry into service, which explores a former preparatory career and post-integration implementation path for preschool teachers.

\section{Solve the Problem of Immobilization of Traditional Practice Knowledge}

Apprentices have become reflective practitioners. They have transformed the traditional practice into a two-dimensional construction of the field under the support of the practice community. Through active work, students have the time and space to reflect the topic contents and themselves. The acquisition of the state of knowledge becomes a dynamic generation in reflection, which avoids the phenomenon that students are prone to fall into the "apprentices style" and the lack of force after the work.

The target state of "theory and practice pouring model" under the real field can show its advantages by comparing the knowledge state of preschool teachers training in the three styles: 


\begin{tabular}{|c|c|c|c|}
\hline Name & Traditional theory teaching & $\begin{array}{l}\text { Traditional practice } \\
\text { teaching }\end{array}$ & Teaching in a full practice field \\
\hline Standard style & Class theory knowledge & $\begin{array}{l}\text { Kindergarten following } \\
\text { class practice }\end{array}$ & $\begin{array}{l}\text { Books supported by community practice } \\
\text { - field bidirectional construction }\end{array}$ \\
\hline $\begin{array}{l}\text { Teaching } \\
\text { metaphor }\end{array}$ & Steel & Sediment & Reinforced cement \\
\hline $\begin{array}{l}\text { Teaching } \\
\text { concept }\end{array}$ & Professorism & Apprenticeship & Reflective practitioner \\
\hline $\begin{array}{c}\text { Knowledge state } \\
1\end{array}$ & $\begin{array}{l}\text { Failure to link theory } \\
\text { knowledge with individual } \\
\text { experience }\end{array}$ & $\begin{array}{l}\text { Rough, unrefined } \\
\text { experience fragments }\end{array}$ & $\begin{array}{l}\text { Theory knowledge and field knowledge } \\
\text { have been linked }\end{array}$ \\
\hline $\begin{array}{c}\text { Knowledge state } \\
2\end{array}$ & $\begin{array}{l}\text { Theory knowledge is } \\
\text { stereotyped and } \\
\text { non-situational }\end{array}$ & $\begin{array}{l}\text { Perceptual experience is } \\
\text { not conceptualized, } \\
\text { standardized or typed }\end{array}$ & $\begin{array}{l}\text { Field experience has been summarized } \\
\text { into related concepts }\end{array}$ \\
\hline $\begin{array}{c}\text { Knowledge state } \\
3\end{array}$ & $\begin{array}{l}\text { Book knowledge is } \\
\text { non-meaning "neck learning" }\end{array}$ & $\begin{array}{l}\text { Experience repetitive and } \\
\text { monotonic fatigue }\end{array}$ & $\begin{array}{c}\text { Transformation and network } \\
\text { establishment of general knowledge and } \\
\text { situational knowledge }\end{array}$ \\
\hline $\begin{array}{l}\text { Knowledge state } \\
4\end{array}$ & $\begin{array}{l}\text { Theory knowledge given to } \\
\text { students in one direction }\end{array}$ & $\begin{array}{c}\text { Experienced emotional } \\
\text { experience, experience is } \\
\text { unintentional, unstable or } \\
\text { non-logical }{ }^{1} \\
\end{array}$ & $\begin{array}{l}\text { Abilities construction from novice, } \\
\text { skilled to expert and dynamic generation } \\
\text { of practical knowledge }\end{array}$ \\
\hline $\begin{array}{l}\text { Knowledge state } \\
5\end{array}$ & $\begin{array}{l}\text { Face theory knowledge } \\
\text { world, which is the } \\
\text { crystallization of human } \\
\text { experience, take exam as } \\
\text { test standard }\end{array}$ & $\begin{array}{l}\text { Face the world of in-field } \\
\text { experience (situational), } \\
\text { use "act" as a test standard }\end{array}$ & $\begin{array}{l}\text { Theory knowledge is only a fusion of } \\
\text { the world and the real world experience, } \\
\text { and community sharing and recognition } \\
\text { are the inspection standards }\end{array}$ \\
\hline $\begin{array}{l}\text { Knowledge state } \\
6\end{array}$ & $\begin{array}{l}\text { Attitude is injected, value is } \\
\text { strengthened and external }\end{array}$ & $\begin{array}{l}\text { Attitude is diffuse, value is } \\
\text { free, fuzzy and } \\
\text { non-ideological }\end{array}$ & $\begin{array}{l}\text { Attitude is internal and consistent. Value } \\
\text { is generated, clarified, calibrated and } \\
\text { unified }\end{array}$ \\
\hline
\end{tabular}

The theory and practice pouring model is a transcendence of the way of thinking under the change of knowledge concept, realizing the reasonable transformation of the way of thinking of theory and practice, and finally crossing the misunderstanding between theory and practice.

\section{Form "1336" Operating Method in Practice Course Teaching}

"1" refers to a system; " 3 " refers to three platforms; "3" refers to three teams; " 6 " refers to six-step guidance.

A system refers to the practice-oriented curriculum teaching system, including practice orientation of the curriculum module, the practice orientation of the curriculum operation, and the practice orientation of the curriculum evaluation.

The practice orientation of the curriculum module contains five modules, one is basic skills curriculum for preschool teachers based on operability, one is education curriculum with emphasis on knowledge and practice, the third one is the curriculum emphasizing practical knowledge and skills, the fourth is practices and internships that correspond to related courses; and the fifth one is graduation thesis and related education site surveys.

Course practice orientation: teaching method innovation is the integration of all subject knowledge and skills in the actual kindergarten practice field. By group teaching, virtual in-field teaching, real live teaching and other teaching organization forms, all the practice of the course run as a whole, which is systematically positioned and coordinated. Once students enter the school, they have an overall understanding of the knowledge and abilities of preschool teachers in the practice field, and then they can accurately locate each subject.

Practice orientation of curriculum evaluation: Establish growth files to strengthen the process of assessment; simulate teaching focuses on practical performance assessment; artistic skills assessment should be instead by match; set innovation credits, declare project application innovation practice, and comprehensive practical ability of students should be assessed in 
professional scientific research projects.

The three platforms refer to the integrated training room for preschool education, the student organizations for professional development of preschool teachers (the extracurricular learning community), and the professional development schools for preschool teachers (including the practice base); which form the material platform for the implementation of practice-oriented curriculum.

The three teams refer to the curriculum training practice teacher team, kindergarten practice instructor team, and professional curriculum teacher team, which are three different types of teacher teams. Professional skills teachers have no longer keep their professional skills goals at the level of craftsmen. The practice kindergarten instructors under the practice community have no longer remain in the emotional experience and accumulation of experience. They have theoretical thinking, critical reflection, and professionalism. Professional tutors have broad professional knowledge, deep professionalism, proper professional methods and professionalism.

The six-step guidance refers to the teachers of the three teams who form the situation as practice instructors and form a six-step guidance that situational preparation - operation process - record reflection - multiple evaluation - exchange sharing (group, class, grade group, the largest community group) - problem creation, which takes the practice community as the carrier and guides students to learn the basic reflective techniques, specifically describe the activities or process, capture the scene to feel, mirror the image or transpose to understand themselves, reflect with the practice community, reflect and solve questions, activate theory knowledge, situationality understand theory and reconstruction of the theory and turn reflective thinking into action by taking Guidance of Practice, Professional Skills Guidance, Guidance on Student Professional Innovation, Thesis Guidance, and Guidance on Professional Development Archives as the contents. Reflective practitioners' conscious state: Always consider himself as learner and maintain an open attitude to explore and research to obtain tools that support his own professional development. Treat critical knowledge and theories with a critical attitude. Recognize the relevance of theory and practice and grasp the appropriate conversion method. Students achieve practical educational knowledge before they enter the teaching position. After entering the profession, their professional ability will not stop at the institutionalized science and technology, theoretical knowledge or reasonable skills. Instead, they integrate the process of dynamic knowledge generation and rethink the problem situation. Reflection and adaptation to the development of reasonable judgments of these problem situations avoid the solidification of knowledge state.

\section{New "Theory and Practice Pouring Model" Shows Effectiveness}

\section{Ecological Development of Teaching Environment}

The new "theory and practice pouring model" created the ecological teaching environment for in-field pouring theory and practice. In terms of philosophy, it further promoted the relationship between teacher knowledge, teachers' intelligence structure, and the relationship between theory knowledge and practice knowledge.

The practice model of new "theory and practice pouring model" has effectively promoted the construction of practice textbooks. The practicability and practice orientation of textbooks are more in line with the transformation and development of local preschool education major and the strategic needs of serving localities.

\section{The Comprehensive Development of Students' Practical Ability}

Students found a reasonable channel for integrating theory with practice in practical teaching. The eco-style practical environment provides students with an opportunity to continue entering the education scene. Students' professional capabilities have been improved and they can quickly adapt to various tasks in the kindergarten.

Throughparticipation-awareness-harvesting-experience-reflection practice activities, students of preschool education major of local universities and colleges have initiated projects in national and provincial innovation projects and have won awards in various competitions. 


\section{Multiple Roles Reciprocity for Teachers and Their Self-development}

The main members of practice community are kindergarten teachers, students participating the practice and college teachers who break the traditional limits and realize integration of experience and knowledge and professional growth in different fields. Teachers play a role of coordinators, friends and mentors at the same time in all practical activities, reciprocating multiple roles and nurturing their own growth.

The experience of practice has a leading and enlightening effect on the scientific research of local college teachers. The universality and urgency problems found in practice process can often bring inspiration for the selection of scientific research topics.

\section{Acknowledgement}

Fund Project: Special Topic "Transformation of Preschool Education for Local Colleges and Universities in Shaanxi Province Based on Full Practical Concept" of Shaanxi Provincial Department of Education of 2016 (16JK2185)

"Research of Preschool Education Training Model Based on Practice Concept" of Education and Teaching Reform of Xi'an University of 2015 (JG2015B050)

\section{References}

[1] The Ministry of Education promulgated Professional Standard for Kindergartens Teachers (Trial) [2012] No. 1 Document in 2012.

[2] Kewei Xu, Qi Wei, Multiple Path Exploration: A New Model of "Two Transformation and Two Combination", Multi-object Cultivating Skilled Application Talents_-Exploration and Practice of Applied Talent Training in Xi'an University of Arts and Sciences, China Education News, 14th February 2014.

[3] Wei Du. How We Think, Experience and Education. Beijing: People's Education Press, 2005.

[4] Bingde Li. An Analysis of the "Two Surface" Phenomenon in Educational Theory and Educational Practice. Educational Research, 1997(7).

[5] Changfu Xu. Re-understanding the relationship between theory and practice [J] Towards practical wisdom - exploring new approaches to practical philosophy. Beijing: Social Sciences Academic Press, 2008.

[6] Gagne. Learning conditions and teaching theory. Shanghai: East China Normal University Press, 1999.

[7] Wei Du. Experience and Nature. Translated by Gao Jianping. Beijing: Commercial Press, 2005.

[8] Jinliang Qin, Zongshun Zhu. The Transformation of Preschool Teacher Education in China. Beijing: New Age Press, 2008.

[9] Elbaz F.Teacher Thinking;A Study of Practical Knowledge.London;Croom Helm,1983.

[10] Changfu Xu. Theoretical Thinking and Engineering Thinking. Shanghai: People's Publishing House, 2002.

[11] Lan Ye. Thinking through the break. Chinese Journal of Education, 2001.

About the author: Wang Xiaoyi (1969- ), Female. Place of origin: Shunping, Hebei. Professor of Preschool Education Department of Xi'an University. Mainly engaged in preschool children's literature, preschool education practice research. 